\title{
札幌における広幅員街路網の形成に関する考察 \\ 一1936年都市計画街路における緑樹帯構想について一 \\ A STUDY ON THE 1936 PLAN FOR BOULEVARDS NETWORK IN SAPPORO
}

\author{
鈴木 栄 基* \\ Eiki SUZUKI
}

\begin{abstract}
The meaning of the 1936 plan for boulevards network or park system in Sapporo were analyzed on following aspects.

1. The boulevards network were aimed to provide space for a disaster prevention under the influence of the big fire in Hakodate city on March 1934.

2. The boulevards were modeled on Odori-park and could be crassify with three patterns, prototype, riverside-type and farmland-type.

3. The background of revision about boulevards network was caused by urbanization, esspecially on farmland-type.

4. Through the 1936 plan, we could recognize the park system realized trunk-road network.
\end{abstract}

\section{Keywords: plan for street network, park sytem, disaster prevention} 街路網計画、公園緑地系統、防災

\section{1. 本研究の目的と方法}

近代都市計画の計画手法の一つにパークシステムがあり、アメリ 力合衆国で発達したものとして知られている。石川によれば、パー クシステムは「正しくは、公園と広幅員街路の系統 (Parks, Parkways and Boulevard System)とよばれるもの」であり、「市街化 に先立ち、公園と広幅員街路を骨格とする基盤整備を行い、良質の 市街地整備を計画的に誘導し、あわせて、水源地、湖沼、河川、段 丘崖、良好な樹林地等の保全・再生を行ったもの」と定義する”。 そして、その意義の一つとして、アメリカにおいて「国土基準線に よる格子型街路システム」にかわり、「河川、湖沼、樹林地などそ の都市に固有の自然条件を都市計画の基碟に据えるという考之方を 普及させることとなった」と指摘する ${ }^{21}$ 。

また、石川によれば、わか国におけるパークシステムは、霞災復 興、戦災復興など防災都市計画を契機として導入され、東京をはじ め仙台、名古屋、神戸、広島、鹿児島などにおける公園と広幅員街 路を代表的事例としてあげている3゙。

一方、越尺は、1936年札幌都市計画街路 (内務省告示第534号、 以下、36年街路と略す) は、パークシステムの考え方を採用して全 市におよふ都市計画道路網が計画決定された国内では唯一の事例だ と指摘している ${ }^{4)}$ 。しかし、越沢は、36年街路にパークシステムが
導入された背景や計画の実現過程などにははとんど触れていない。 本研究では、36年街路の策定過程および実現過程を通して、かが 国の近代都市計画におけるパークシステムの意義の一端について明 らかにすることを目的とする。なお、本研究に当たっては、従来の

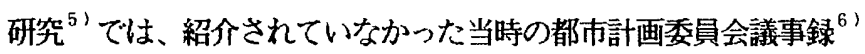
を活用することで、パークシステムの導入根继について新たな見地 を得ることとする。

\section{36 年街路の策定過程}

36年街路は、'27年に計画决定された都市計画区域 ${ }^{7}$ の全域を対 象に、計60路線（総延長距離247km）からなり、都心部では格子型 を、郊外域では放射環状型のパターンをそれぞれ形成していた。ま た、幅員55m以上の広路 (緑樹帯) 7本を含み ${ }^{\mathrm{s}) 、 い お り る ハ ゚ ー ク ~}$ システムを形成していた（図1、表1）。これらの配置パターンは、 現在の幹線街路にほほ相当守る。

札幌市史によれば、36年街路の計画案は、内務大臣に申請する19 36年 4月までの過程で、'29-30年䪸に試案として第一次計画案が、 ’31３2年頃に系統的見地から检討を加之た第二次計画案が、33 34年頃に最終的な計画案がそれぞれ作成されたとあり ${ }^{111}$ 、少なく とも3つ以上の案が存在していたことが明らかにされている。 


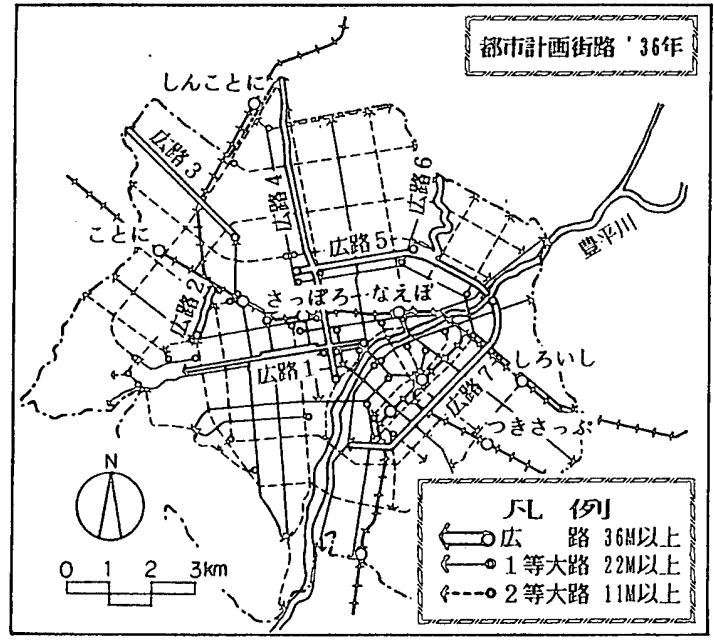

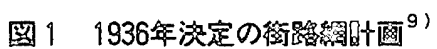

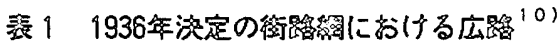

\begin{tabular}{|c|c|c|c|c|c|}
\hline & 名莗 & 点 & 您点 & 婹 $(\mathrm{km})$ & 漼員 (⿴囗十) \\
\hline & 太政 & 大倩相 & 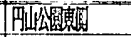 & 4.3 & 58简 \\
\hline & 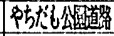 & Pulf5条椺 & 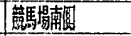 & 1.5 & $55 \sim 110$ \\
\hline & 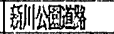 & 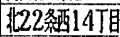 & 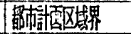 & 3.6 & 45間 \\
\hline 4 & 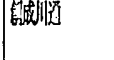 & 南7条梖2丁目 & 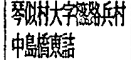 & 7.5 & $55-67$ \\
\hline & 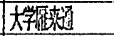 & & 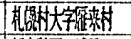 & 4.9 & 55 \\
\hline & 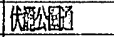 & 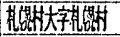 & 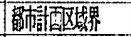 & 2.9 & $55-88$ \\
\hline & 白砰岸祖 & 白碄大字上的础 & 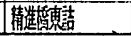 & 7.2 & 55 \\
\hline
\end{tabular}

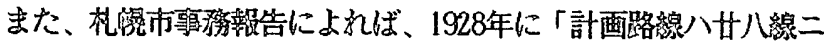

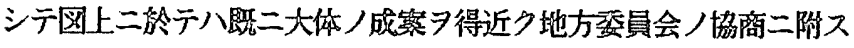
へク造メッャアリ」、1930年に「現在予定線延長約五万六千四百二 十間 (韵103k田。拥教)」、1931年に「現在二於与儿路線予定延長八

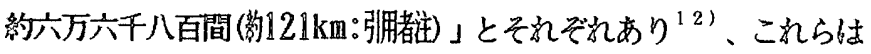

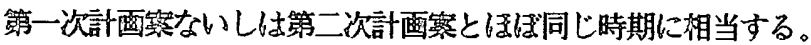

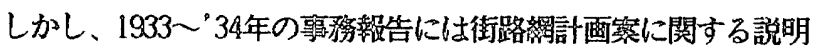
がなく、聂紤的な計画繁については知ることができない。

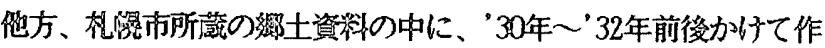
成と記される「計图图 1 号」および「同 2 号」と作成時期が明記さ

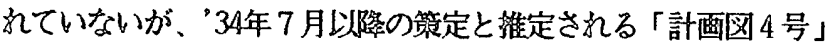

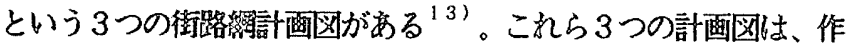
成時期および内容から考えて前述の札煶市堮が説明する第一次計面

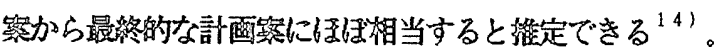

これら3つの計图园加ら、36年街路籍定の背景の一端が把握でき

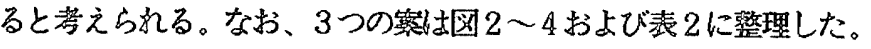
その結哭、「計画图 1 号」および「同 2 号」は、その路線延長（約

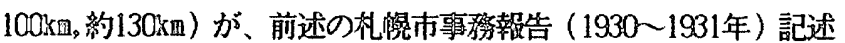
の路䌨予定延長（約103km，約121km）と頩似し、2つの計画图が1930 ～1931年頃に撒けて作成されたことを襄付けるものと推定できる。 また、これらの計圂图から次の特徽を誖みとることができる。

筑一点は、街路網の配置パターンと広路 (緑樹帯)の有無である。 「計画図 2号」仙「同 1号」に比べて、放射系およひ摆状系の路線

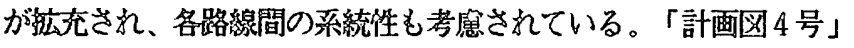
は、先の 2 管に比べて路線数が倍程度に增え、新たに 7 本の広路が

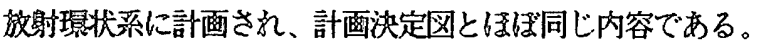

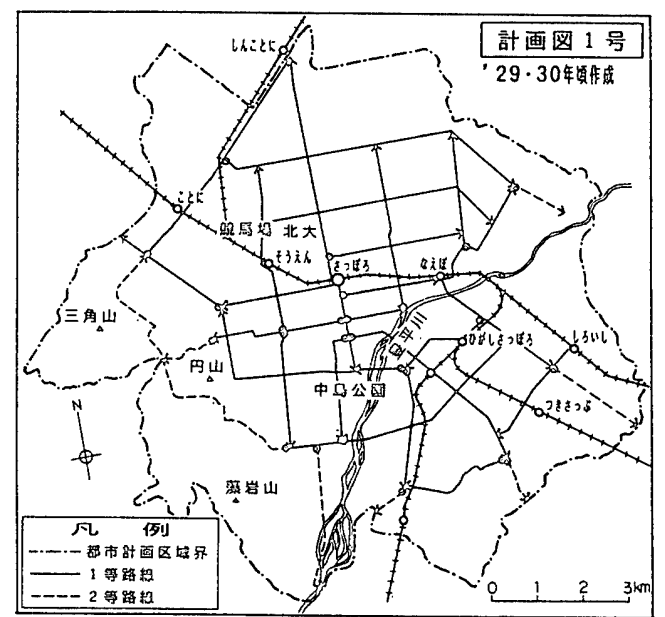

圆2 旪圆图 1 号 $^{(5)}$

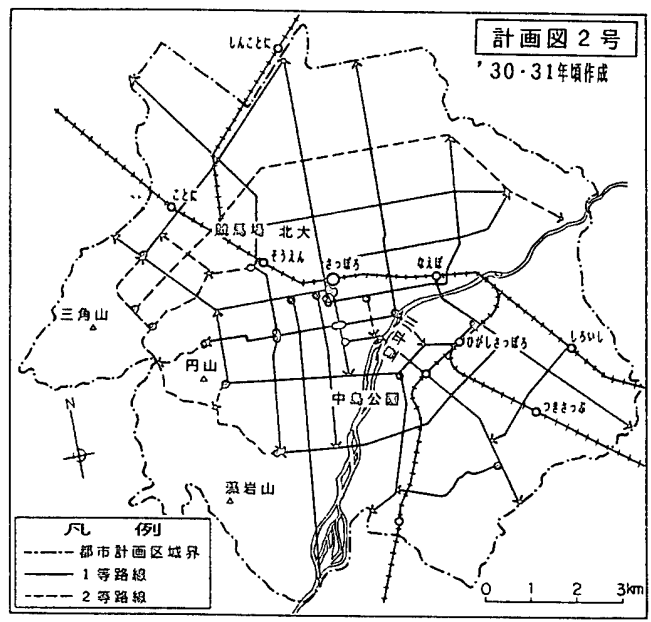

图3 旪國图2 ㅁㄱㄱ $^{161}$

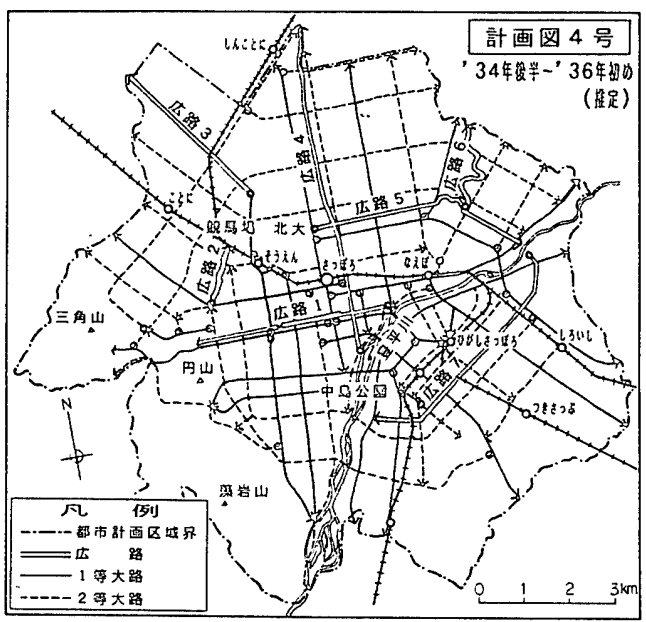

圆4 旪图国4 号 ${ }^{171}$

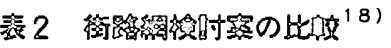

\begin{tabular}{|c|c|c|c|c|}
\hline 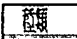 & 路留鼠 & 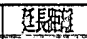 & 公路 & 作成時期 \\
\hline 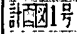 & 33 & 约 $100 \mathrm{k}$ & $\$ L$ & $30-31$ 年 \\
\hline 䶂2 & 28 & 约130k田 & なし & '31～'32年 \\
\hline 讄国4 & 58 & 教240kn & 7路線 & '34年7月＇36年的（推定） \\
\hline 謤洪定国 & (2) & $247.1 \mathrm{~km}$ & 7 路線 & 36年10月告示 \\
\hline
\end{tabular}


第二点は、街路網と既存の緑地との関連性である。「計画図 4 号」 では、広路は市内を流れる河川に沿って配置され、その終起点で豊 平川あるいは競馬場や大学などの緑地と連絡している。「計画図2 号」の一部の街路にも河川に沿った配置が見られるが、「同 4 号」 のような緑地との関連性は明確でない。

これらの特徴をもつ「計画図 4 号」は、計画決定罒と酷似し、両 者が同じ計画思想によって作成されたと理解でき、計画決定案は、 後述するように、34年3月に発生した函館大火の復興計画の影響 を受けていた。すなわち、36年街路は長期にわたる検討の過程で、 ’34年函館大火の影響を受けた内容になったことが想定できる。

\section{3. 緑樹带の導入目的とその特徽}

\section{(1) 緑樹帯の導入目的}

36年街路にパークシステムが採用された理由について計画の決定 理由書は、次のように説明している ${ }^{19) 。 ~}$

市ノ中央部八明治四年開拓使ノ計画二係り従テ街区整然其ノ幅 員広闊ニシテ概市十一間及六間习有ス殊二大通卜称七ラルルモ ノ八其ノ幅員五十八間习有ス卜踓モ市ノ発達二伴七不規則十ル 街区随所二現ハレ殊二市内ノ一部及隣接町村ノ区域八道路甚夕 不整而モ幅員狭隘二シテ近代的交通機関ノ利用二適セサルモ， アリ茲二於テ街路網計画ヨ決定シ都市棈筑ノ根幹ヨ示シ交通上 ノ欠陥习除去スル卜共二系統的交通網习確立スルハ実二現下， 急務二属入今街路計画习樹ツル二当り地勢、地域、河川、鉄道 等ノ関係习考虑シ先ツ中央部八区画整然夕ルモノアリト雖モ多 少ノ不規則ナキニ非午ルヨ以テ之ヨ整正スルニ止メ稍々都心部 习離ルルニ及七漸次放射並二環状二幹線 7 更二是等幹線 7 基準 トシテ補助幹線习配置シ以テ土地ノ状況二適応セシメタリ 尚今後ノ都市施設トシテ緑樹帯ノ存置八独り市民ノ保健及都市 ノ美観上必要十ルノミナラス偶々火災其ノ他ノ災禍ノ笑発二際 シテ八是等施設二俟ツへキモノ大ナルモノアルラ以テ現在市内 及近郊二点在セル公園及自然緑地卜連保 計画公園ノ連鎖夕ラシムへク広路及緑樹帯习考慮シタル幹線街 路习配シタリ斯クシテ得夕ル路線数六十延長約二百四十七粁二 達入

すなおち、36年街路の策定理由の第一点は、明治期の開拓使時代 に計画された格子型の市街地に加えてその外側に放射環状系を導入 して「将来二於々ル交通系統习確立シ新市街構築二対スル正シイ基 準ヨ与ヘル」20)ことであった。また、第二点は、緑樹帯は「交通 街路トシテ計画シタモノニ非ズシテ、主トシテ市民ノ保健衛生或八 都市ノ美観习増シ、火災其ノ他非常時ノ際二於ケル災嗐防止或八避 難习容易十ラシムル為／施設、更二一朝外国力ラ空襲习受ケ夕様ナ 際二於ケル避難」 ${ }^{21}$ など防災機能のためだとし、既存の公園およ び自然緑地との連係を考虑に入れたことである。

以上のように、36年街路は、河川ほまか自然緑地の関係を考虑した 放射環状型の街路網計画であり、緑樹帯は防災などを目的に尊入さ れたことになる。

次に、緑樹带の構造および導入の根拠について、都市計画委員会 では、以下のように説明されている22)。

真ン中ヨ植樹地帯ニシテ其ノ両側二通路习設クル設計二致シテ

居リマシテ、大部分植樹地帯ニシテ通路八極ク幅員ノ狭イ散歩
居リマシテ、大部分植樹地帯ニシテ通路八極ク幅員ノ狭橵歩 道程度ノモノヨ大体考へデ設計シデ居リマス (中略) 其ノ「七 ント」八無論現在ノ大通ニ在ルノデアリマス、更ニ引続イテ御 承知/函館大火/経験二監ミマシテ、函館復興計画ノ内二モ此 ノ「グリンベルト」式ノ災㲅施止ノ為ノ街路ガ採入レラレテ居 ルノデアリマシテ、今回ガ之デ二回目デアリマス

これによれば、緑澍帯は、交通が主目的でなく、火防線として計 画されたと言われる既定路線の大通にならつたことになる。大通は、 '34年函館大火の復興計画および札幌の36年街路のプロトタイプで あったと考えられる。

(2) 緑樹帯のパターンについて

次に、緑樹帯の配置について、都市計画委員会では以下のように 説明されている ${ }^{23) 。 ~}$

是等ノ地積八官有地二属スルモノガ大部分デ堤塘敷地等ニナツ テ居リマスガ、夫々関係当局卜打合シマシテ、此/際街路ノ区 域二編入スルコトヨ至当卜認メテ計画致シタノデアリマス

すなわち、緑澍帯の配置は、官有の堤塘敷地（河川緑地）を活用 したこと、また、民有地に計画された環状系の広路（5号および 7 号)は、以下のように説明されている24!。

現在ノ所大部分農耕地二利用サレテ居リマシテ、建物モ余り建 ツテ居リマセヌノデ、之ヨ計画街路ニ指定シマシテモ左程ノ犠 姓习与人ナイコトト考へタ次第デアリマス

すなわち、緑樹帯の計画線に市街地建築物法（1926年札幌市域適 用。以下、物法と略す) が適用されて建築制限が生じた場合、「斯 様十大規模/道路习取ツテ而モ補償 7 出サナイデ長イ年月/間二結 局道路トシテ使用スルト云フコト八相当考へ物デアルト思ヒマシテ、 サウ云フ見地カラ「グリンベルト」ノ配置ノ籄所八余り耐へ難キ㩘 牲习住民二与へズ然モ最モ絶好十箇所卜云フコトニ目標习置イ夕」 25 )ためであり、「民地デアツテ而モ家力建ツテ居儿様十所八成ル ベク除外シ度イト云フ気持デ立案シマシ夕」 ${ }^{26)}$ と説明された。

また、周辺町村部にまたがる豊平・白石方面の緑樹帯（白石平岸 通）は、付近の区画整理の動きを出来るだけまとめて「区画整理設 計ノ中ニ「グリンベルト」ト云ツ夕様十災害防止ノ目的习持ツ夕モ ノヨ採入レテ」 ${ }^{271}$ と説明された。

以上から、パークシステムの導入に当たっては、河川などの官有 地が利用され、また民有地が対象になる場合には、建築制限の影響 が少ない農耕地などの地域が選択されていたことが明らかである。

しかし、実際には、物法の施行区域が、都市計画区域全体に及ば なかったため、「建築物法の執行区域外に於ける都市計画に決った 所の路線の仮設建築物の制限」 ${ }^{28)}$ か望まれていた。

他方、7本の緑樹帯は、湧泉を水源にした伏籠川、琴似川支流を 含み、またすべての路線が1939年に風致地区の指定を受ける点から 考えて、緑樹帯棈想には水源地および河川沿岸の樹林帯などの自然 環境の保全に通じる機能があったと考えられる。

以上から、36年街路におけらる緑樹帯の配置パ夕ーンは、当時の土 地利用の実態に即して、以下の3つのタイプに分けることができる。 a) プロトタイプ: 広路 1 (大通)

b) 河川緑地（官有地）タイプ: 広路 2 、広路 3 、広路 4 、広路 6 に該当する路線

c）農耕地（民有地）タイプ: 広路 5、広路 7 に該当する路線 


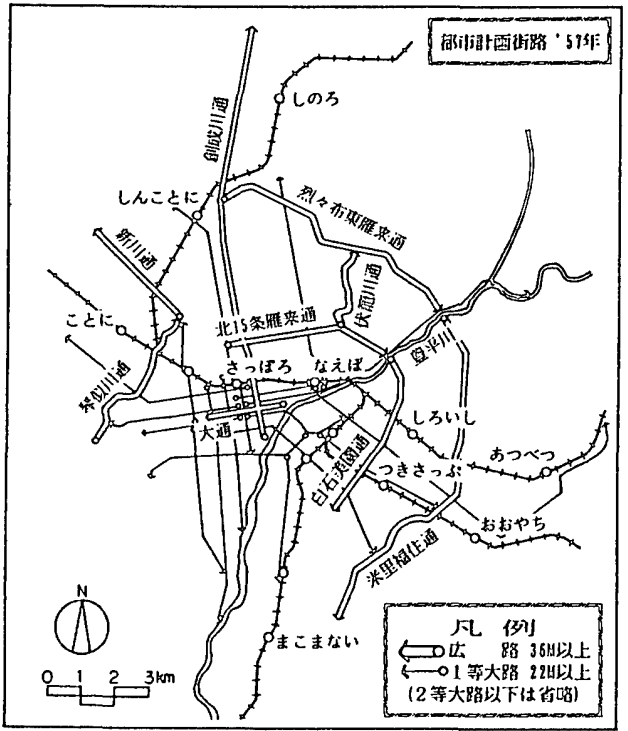

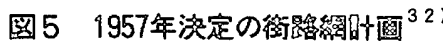

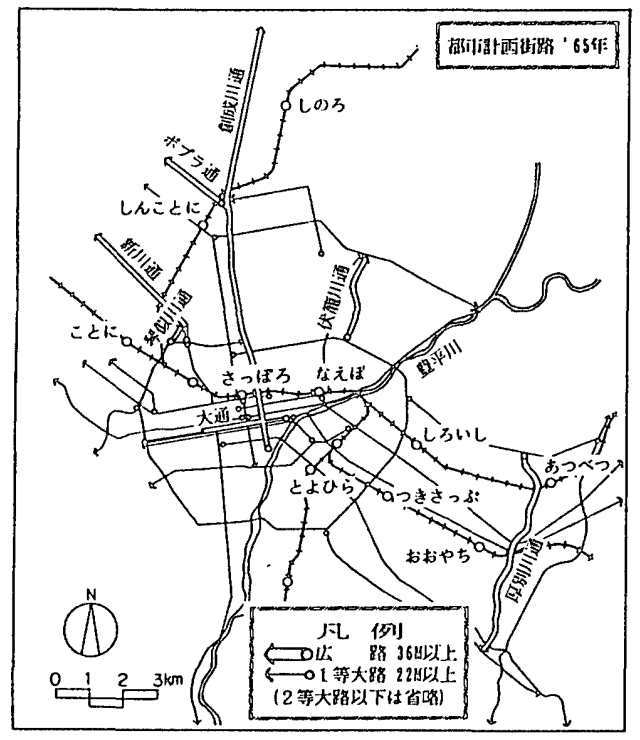

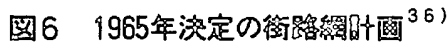

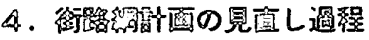

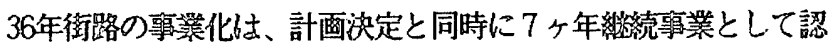

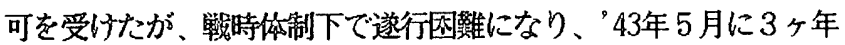
延長されたもののそれ以降の亭鄴は中止の状態であった ${ }^{291}$ 。

鞮後の都市計画街路の見直しは、周辺町村との合併による都市計 图区域の拡大や急激な市街化にともなって頻繁に实施された。その うち街路網計西の全面的な変更は、用途地域とともに’57年、'66年、 '73年の3回実施されている ${ }^{30)}$ 。これらの見直しを通して、主とし て環状系の緑樹帯がどう报われたのかを簡単に整理する。

(1) 1957 (昭和32) 年の見直し

市域の発展膨張に対応した都市計画は、'55年 7 月設置の札幌市

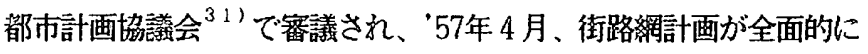
見直された（建設省告示第665号、以下、57年街路と略す。図5）。

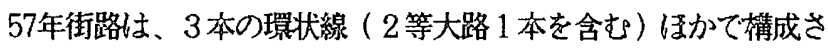

れ、36年街路の広路 5 おび広路 7 は「中心市街地を囲む緑地的な もの」と位置づけ「最小限度の幅員で効用を图るべく $36 \mathrm{~m}$ 程度」と

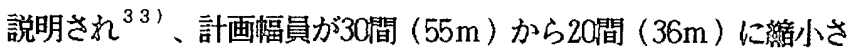
れた。また、「市街地の無制限に連担化するのを防ぐため」 ${ }^{341}$ と いう理由で新たに広路 8 おび広路 9 (烈々布䅫雁苏通および米里 福住通、ともに計画幅員 $44 \mathrm{~m})$ ) が最外側に追加され、「緑地地域の 効用を最大限に期待して」 ${ }^{35)}$ と説明された。

（2）1965（昭和40）年の見直し

57年街路は、その後の市街地の拡大で大幅に見直され、'65年 7 月に「 1 環状 5 大放射路線」とよ占新街路絧計画（建設省告示第16 69号、以下、65年街路と略す。図6)により、環状通力゙学入された。 環状通は「放射交通を直接暗心部に尊入することは既定街路が喀子 状に完成されていることから、多大の混乱をまねくので、都心周辺 の市街地部に強力な㻴状街路を設定し、これにより分散等出入を図 るとともに、都心部を通過する市街地内交通を迁回せしめる」37) と説明され、57年街路の北15条雁来通 (36年街路の広路5に相当)、 白石美園通（36年街路の広路 7 に相当）、琴似川通（36年街路の広 路 2 に相当)などをつなぐものであった。

以上の上うに、65年街路までの街路網の見直し過程で、環状系の 緑樹帯は、交通幹線として位置つけられたと考えられる。

（3）1973（昭和48）年の見直し

'73年 4 月の見直し (北海道告示第 1108 号、以下、73年街路と略 す)は、市域の南泉に計画された厚別副部心とその後背地の菓部地 域開発 ${ }^{38)}$ 、および市域の北際に位置する石狩湾新港開発 ${ }^{39)}$ に対 応した逜絡道路の整備、あるいい市街化区域と市街化調整区域との 区域区分にもとづくためと説明された

また、街路の名称惊、通過する地名にそって改められ、等級・番 号か整理された結果、広路という等級区分は廃止された。

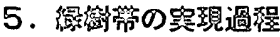

\section{（1）緑樹帯の計画変面の経䋎}

36年街路で尊入された緑樹帯について、今日の幹線街路のパター ンを形成する65年街路までの計画変更の経繶を簡単にまとめる ${ }^{41}$ 。 a) 広路 1 (大通)

大通は、'52年 7 月の街路網の見直し（䞨設省告示第930号、以下、 52 年街路と略す) により、創成川通〜大通西 $3 丁$ 目間の幅員が36間 (65口) から $105 \mathrm{~m}$ （50間）に統一された。その後、65年街路では、 終点が西28丁目まで延長になり、延長部分の幅員は27mであった。 b) 広路 2 (やちだも公園道路)

やちだも公園道路は、52年街路で、最大幅員が $110 \mathrm{~m}$ (60間) か ら85m (50間)に、57年街路では、路線位置が西方の琴似川沿いに 移動し、起冬点か琴似町宮の麻〜同町八亁間とされ、琴似川通に改 称された。他方、旧路線沿いでは、’61年からの北円山地区士地区 画整理事業などによって、污れた河川か整理され、その一部に「や ちだも公園」(0.6ha) が整備された。また、65年街路では、北端 の一部区間630mだけを残して、残り4.5kmは北15条雁来通及び白石 平岸通の広路とともに畹状通 (一等大路) に統合された。

\section{c) 広路 3(新川公園道路)}

新川公園道路ま、当初の幅員のまま、終点が延長された。すなお ち、57年街路で、新川通に改称され、65年街路で、北19条西14丁目 
表 3 広路('36年)の垔離・幅员の变更経緯 ${ }^{4}$ )

\begin{tabular}{|c|c|c|c|c|}
\hline \multicolumn{3}{|c|}{ '36年計画决定時 } & '57年の & '66年の \\
\hline \multirow{2}{*}{$\begin{array}{l}\text { 広路 } 1 \\
\text { 大通 }\end{array}$} & $\mathrm{L}$ & 4. $3 \mathrm{~km}$ & $2.4 \mathrm{~km}$ & $4.3 \mathrm{~km}$ \\
\hline & W & $105 \mathrm{~m}$ (58間) & $105 \mathrm{~m}$ & 105 m \\
\hline \multirow{2}{*}{ 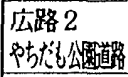 } & $L$ & $1.5 \mathrm{~kg}$ & $5.1 \mathrm{~km}$ & $0.6 \mathrm{~km}$ (位) \\
\hline & $w$ & $55-110 \mathrm{~m}$ & $36 m$ (20周) & $36 m$ \\
\hline \multirow{2}{*}{\begin{tabular}{|l} 
広路3 \\
新川公通道路 \\
\end{tabular}} & $\mathrm{L}$ & $3.6 \mathrm{~km}$ & $3.6 \mathrm{~km}$ & $3.9 \mathrm{~km}$ \\
\hline & $w$ & $80 \mathrm{~m}$ (45間) & $80 \mathrm{~m}$ & $80 \mathrm{~m}$ \\
\hline \multirow{2}{*}{\begin{tabular}{|l} 
公路 4 \\
淢川道
\end{tabular}} & L & $7.5 \mathrm{~km}$ & $12.6 \mathrm{~km}$ & $12.5 \mathrm{~km}$ \\
\hline & w & $55-67 m$ & $40-57 m$ & $40-57 m$ \\
\hline \multirow{2}{*}{$\begin{array}{l}\text { 広路 } 5 \\
\text { 大学猚栟通 }\end{array}$} & L & $4.9 \mathrm{~km}$ & $4.9 \mathrm{~km}$ & - (住) \\
\hline & W & 550 (30間) & $36 \mathrm{~m}(20$ 贯) & 36 m \\
\hline \multirow{2}{*}{$\begin{array}{l}\text { 広路 } 6 \\
\text { 性公継通 }\end{array}$} & L. & $2.9 \mathrm{~km}$ & $5.6 \mathrm{~km}$ & $2.9 \mathrm{~km}$ \\
\hline & * & $55-88 \mathrm{~m}$ & $55-88 m$ & 40 m \\
\hline \multirow{2}{*}{$\begin{array}{l}\text { 広路 } 7 \\
\text { 白砰岸通 }\end{array}$} & $\mathrm{L}$ & $7.2 \mathrm{~km}$ & $5.5 \mathrm{~km}$ & - (住) \\
\hline & W & 550 (30间) & $36 \mathrm{~m}\left(20 \mathrm{i}^{\mathrm{i}}\right)$ & 36 m \\
\hline
\end{tabular}

L:延長距離 冈:主な幅員

(注)広路 $2 \cdot$ 広路5・広路7は環状線(一等大路)に統合

一 北22条西14丁目間（旧一等大路）が追加され、73年街路以降、石 狩湾新港方面への基幹道路として位置つけられた。

d) 広路 4 (創成川通)

創成川通は、都心部の幅員は維持されるが、路線の北側で幅員が 樎小された。また、 48 年度に南 6 条一南 1 条間に緑地帯が造成さ れるが、'67年以降の札幌オリンピック関連事業の街路整備によっ て緑地帯の大部分が削られた。また、57年街路では、北13条以北の 幅員から5m以上から $44 \mathrm{~m}$ に蹜小になった。

\section{e) 広路 5 (大学雁来通)}

大学雁来通は、57年街路で、幅員か $555 \mathrm{~m}$ (30間) から $36 \mathrm{~m}$ (20間) に栯小され、北15条雁来通に改称された。その後、65年街路では、 白石美園通（旧広路 7 白石平岸通）とともに環状通に統合され、街 路区分が広路から一等大路に変更になった。

f）広路 6 (伏籠公園通)

伏籠公園通は、52年街路で、起点位置の広場が廃止され、57年街 路で、終点が丘珠町まで延長になり、伏籠川通に改称された。その 後、65年街路で、伏籠川が周辺の宅地化にともなう水源の枯渴と活 染問題などを理由に改修 (一部暗渠化)され、起点側の幅員が5 から $40 \mathrm{~m}$ に綞小になり、同時に緑道 $(1.3 \mathrm{~km})$ が整備され、’77年に は終点の延長にともない伏古・拓北通に改称された。

\section{g) 広路 7 (白石平岸通)}

白石平岸通は、” 45 年 2 月の街路網变更 (内務省告示第24号) で、 南よりの白石桑園通 ( 2 等大路) の位置に変更され、'56年 4 月 (建設省告示第576号) に白石美園通に改称された。位置変更の理 由は、隣接地区で 44 年 8 月に東札愰土地区画整理が決定された (内務省告示第461号) ためとされ、緑樹帯は遵入過程で目標にさ れた区画整理の中での採用とはならなかった。また、57年街路で、 終点が美園に短縮、65年街路で、琴似川通 (旧広路 2 やちだも公園 道路）及び北15条雁来通（旧広路 5 大学可来通）とともに環状通に 統合され、区分が広路から一等大路に変更された。

\section{(2) 变更経緯のまとめ}

36年街路の広路 (緑樹帯) について、延長距離及び幅員に着目し、 それらの変更経緯を表3に整理した。また、広路2〜7について、
的画断面 (1936年)

道路) 201010
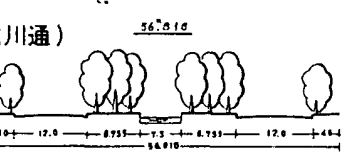$$
\text { ５5:000 }
$$

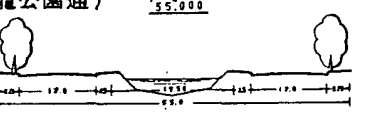

吘:

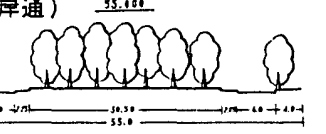

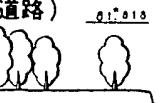

計画断面 (1965年以降)

\section{新川通}
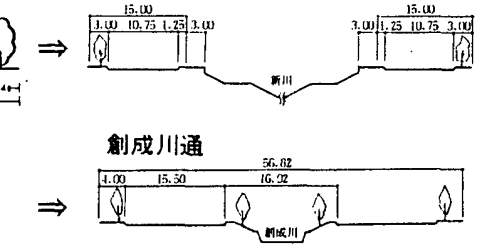

代古 ·拓北通

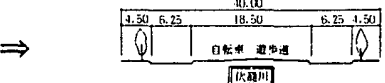

理状通

$\Rightarrow$
图7 緑樹带の計画断面の变化 ${ }^{431}$

計画当初（36年街路）および65年街路以降の断面を図7に示した。 これらから、次の結論を導くことか可能と思われる。

a) 大通を除いた各緑澍帯では、計画幅員の維小あるいは緑地部分 の減少が見られ、市街化の進展にともない、緑澍帯の機能が市民 の保健衛生的なものから交通路に転換されたことを意味している。 b）河川緑地夕イプの緑樹帯は、路線によっては、市街化による水 源の枯渴と污染にともなう河川改修などによって線形、幅員が見 直され、公園・緑地は部分的な整備に限定された。

c）農耕地夕イプの緑樹帯は、河川緑地夕イプに比べて、位置の变 更ないしは計画幅員および緑地帯の大幅な維小など、市街化によ る影響をより強く受けていた。

農耕地夕イプの環状系の緑樹帯が河川緑地夕イプに比較して、計 画の変更が大きかった背景として、街路予定線における建築物規制 の問題が考えられる。

前述したように、36年街路が決定された当初、物法の施行区域は、 札幌市の市域と隣接町の一部に限られ、都市計画区域の約半分程度 であった。このことは、市域外の緑樹帯においては、予想以上に市 街化のテンポが早く、建築物の制限が出来ないことが、緑樹帯の位 置、幅員などの見直し原因の一部になったことを想定させる。

他方、河川緑地夕イプの緑樹帯は、河川という官有地を活用した 計画であったため、計画路線における建築物規制の問題がなく、将 来の路線か担保される結果になったと考えられる。

\section{6. 結䤅}

\section{(1) まとめ}

36年街路における緑樹帯棈想に関して、緑樹帯の導入根拋および その実現過程を通して、次のような点が明らかになった。

a ）36年街路におけるパークシステムは、'34年函館大火を契機に 防災機能を目的として導入されたものであった。

b ) 緑樹帯のモデルは、既定路線の大通であり、これは、34年函 館大火の復興計画の場合と同様であった。

c）緑樹帯は建築制限の影響を避けるために、河川と農耕地を選ん 
で計画されたが、農赫地系だけでなく、河川系の緑樹帯において も、その检の市街化にともなう基盤整備の中で見直されていた。 d）绿樹帯は、市街化の過程で見直されたとはいえ、河川およびそ の他の緑地との関連づけに着目して計面されたことが、放射環状 型の街路パターンの笑現を一定程度担保することを可能にした。

（2）绿橲带棈想の評洒

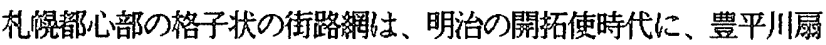
状地上にある原始状態の流路を整理しながら造成された経繶がある。

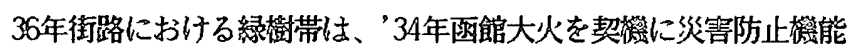
として萿入されたが、それは函館とは邀い、都市計画区域内を豊富 に流孔る河川の流路あるいけ農地などを活用したものであった。こ のことは、その後の市街地の搪大に当たって、幹線街路の突現を担 保するうえで有动であったと考えられる。

また、パークシステムという欧米型の都市計画手法のふ力か国への 嗬入を考之たとき、36年街路の緑樹帯棈想は、将来の都市拡大に先 立って災害防止權能を取り入れる目的で都市固有の自然条件を都市 計画の基礛に据えたという点で、当時のアメリ方諸都市で発達した 計画と同樣に一定の評洒か可能と思名れる。

36年街路の絿樹带は、札幌のアーバンパターンにおいて、格子状

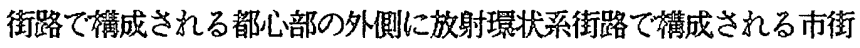

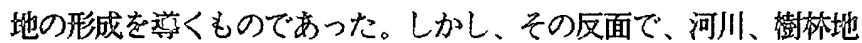
などの自然罢境の保全という緑澍帯本来の㔍能出、相刘的に低下し たと考えられる。

すならち、今日の幹線街路は、36年街路のパークシステムのパタ ーンをかりて成立したのであり、それ都市拡大の中で都市固有の 自然条件を保全することとの引き換えであったと考えられる。

被注

1)～3）石川㪍子 : パークシステム論の近代都市計画への貢献, 緑地環境 科学 (井手久登螎)，朝倉書店, PP. 14-27，1997年

4) 趋沢明: 近代日本都市計画にお引方広幅員道路の系譜, 第8 回日本土木 史研究発表会論文集, PP.54-65, 1988.6.

越沢明 : 济館、札愰、帯広の都市計画-1930-40年代の計画思想の発展一、 第9回日本土不史研究発表会論文集, PP. 181-192, 1989.6.

5 ) 鈴六栄基：1936年机沅都市計画街路の策定過程に閣する考察，日本姪筑 学会大会学術講演梗概集1995年度 (F-1 分冊), PP.705-70.6, 1995.8. 鈴六栄基：札㹸における広路言十画（1936年）の実施過程に関する考察， 日本䞨築学会北海道支部研究報告集, No.69, PP. 425-428, 1996.3.

6 ）都市計画北海道地方委員会: 第14回都市計画北海道地方委員会㗝事速記 録, 北海道大学附属図書館所蔵, 1936年

7 ) 1927 年 1 月決定の札幌都市計画区域は、札幌市域 $(2,416.9 \mathrm{ha}$ ) のほか に豊平町、白石村、札幌村、琴似村、藻岩村の 5 か町村の一部を含み、 合計 10,44 hak及ぶ。

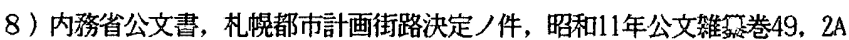
-14-等2234, 国立公文書館所蔵, 1936年 および官報第2927号（1936年 10月2日)によれば、広路の骠準幅員は44m(24間)以上であったが、実 際上は $55 \mathrm{~m}$ (30間)以上が採用された。また、1等 3 類 $(22 \mathrm{~m}$ 以上)が 23 本、 2 等 1 䫛 $(18 \mathrm{~m}$ 以上) と 2 等 2 䫛 $(15 \mathrm{~m}$ 以上)は、あわせて 30 本であった。

$9 \sim 10$ ) 補注 8 ) 資料より作成。

11）札幌市：札璂市史・政治行政篇，PP. 323-332，1953年

12）札幌市：札㡋市事務報告・昭和3年, PP. 167-168, 1929年 同・昭和 5 年, PP. 191-192, 1931年 同·昭和6 年, PP. 169-170, 1932年

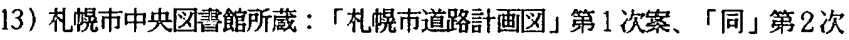
䅗、「札幌市道路計画図四号」、いずれも縮尺 2 万 5 千分の 1 の地形図 がベース。
14）「計画区 1 号」は’29３0年頃作成、「計画図 2 号」は’30－31年頃作成 と記されている。この2枚のベースになっている地形四ば42年の都市 計画区域追加変更後のものであり、作成当時の原計画図を複製したと推 定できる。また、後者の「計画図 4 号」は、’34年 7 月調䇥の地形図に 直接書き込まれている。その作成時期は、(1)地形図への書き込み時期 と同じであれば、’34年 7 月以降で計画決定案が申請された’36年 4 月以 前であり、(2)地形図への書き込み時期よりも前であっても、「計画図 4 号」は計画決定図と酸似し、同じ計画思想によって策定されていると 理解できること、および、36年街路が後述する都市計画委員会䛾事録 の記述より’34年 3 月発生の函館大火の復興計画て導入された炎割防止 疑能にならったものであった点から考えて、早く見ても’34年函館大火 以降と推定できる。なお、「計画図2号」と「同 4 号」との間に存在し ていたと推定される計画図は、現在のところ発見できていないが、この ことが本研究の結論を左右しないものと考えられる。

15１7）補注13）資料より作成。

18）補注13）資料より作成、計画決定図を除く各計画図の路湶数及乙延長距 觹は、园上計測による摡算値。

19) 補注 8 ) 資料による。

20２7）補注 6) 資料PP. 15-21

28）都市研究会：第 4 回全国都市計画協議会記録，都市公論, Vol.20, No. 9 , PP. 58-60, 1937.9.

29) 参考文献 2 ) P. 52

30）机晅市: 札幎の都市計画・資料螎，PP. 38-41，1993年

31 ）札幌市都市計画協議会は、1955年の条例にもとづき、恚合的都市計画の

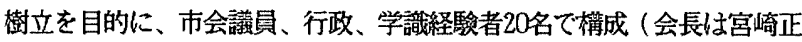
夫)された市長諮問の鹤関。

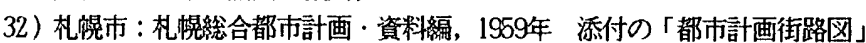
より作成。

33～35）札幌市：札幌総合計画 ·策定蹁，PP.60-68，1959年

36）札幌市：都市計画街路表·最終案, 1966年, 北海道立文書館所蔵, 添付 の「札兒都市計画街路綢图」より作成。

37 ) 紙谷卓三：札幌市の新街路計画, 新都市, Vol.19, №.7, PP.94-100, 19 65.7.

38）查部地域開発は、札幌市の厚別副都心の後背地1,295haを対呂に、’74年 策定の開発基本計画にもとづき民間主峾て開発を進めている住宅団地。

39）石狩湾新港開発は、第 3 期北海道総合開発計画 ('70年 7 月閣䌊決定) にもとづき、石狩湾沿岸の約 $3,000 \mathrm{ha}$ 対象に、'71年より開発を進的て いる港湾を核にした流通および工業団地。

40）机幌市：広報さつぱろ’73年6月版，P.28，1973.6.

41 ）參考文献 2）PP.39-55，補注33）資料，および札幌市企画調餐局繶合交 通計画部資料による。

42）補注33）および補注36）資料より作成

43）参考文献 2)、同 5 )および桃幌市企画調整局総合交通計画部資翻より 作成。

\section{参客文就}

1) 神尾守次: 北海道都市廷設の特殊性, 都市公論, Vol.20, No.7, PP. 160 $-184,1937.7$.

2 ) 札幌市: 札幌都市計画榴要, 1954 年

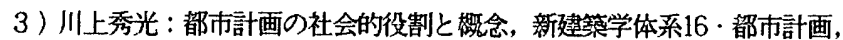
彰国社, PP.3-58, 1981年

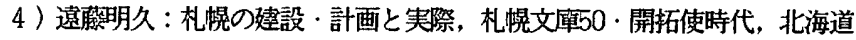
新閪社, PP.48-61, 1989年

5 ) 小谷勝也：都市を支える道路，札幌文庫58 - 札幌の通り，北海道新聞社, PP. 149-189, 1991年

6 ) 越沢明 : 東京の都市計画, 岩波書店, 1992年

7 ) 札幌市: 新札幌市史 - 第 4 巻, PP. 269-320，1997年

(1997年 6 月 9 日原稿受理, 1997 年 9 月 5 日採用決定) 